\title{
Pathophysiology of Functional Gastrointestinal Disorders: A Holistic Overview
}

\author{
Gerald Holtmann ${ }^{a, b}$ Ayesha Shah ${ }^{a}$ Mark Morrison ${ }^{c}$ \\ a Department of Gastroenterology and Hepatology, Princess Alexandra Hospital, Woolloongabba, QLD, Australia; \\ ${ }^{b}$ Faculty of Medicine and Falty of Health and Behavioural Sciences, University of Queensland, Queensland, QLD, \\ Australia; 'Diamantina Institute, University of Queensland, Queensland, QLD, Australia
}

\section{Keywords}

Microbiome · Brain-gut axis · Inflammation · Microbiota ·

Duodenum $\cdot$ Mucosa

\begin{abstract}
Background and Summary: Traditionally, functional gastrointestinal disorders (FGID), including functional dyspepsia or irritable bowel syndrome (IBS), are defined by more or less specific symptoms and the absence of structural or biochemical abnormalities that cause these symptoms. This concept is now considered to be outdated; if appropriate tests are applied, structural or biochemical abnormalities that explain or cause the symptoms may be found in many patients. Another feature of FGID are the highly prevalent psychiatric comorbidities, such as depression and anxiety. It is implied that mood disorders "cause" gastrointestinal symptoms. In fact, epidemiological data now provide strong evidence that in subsets of cases, gastrointestinal (Gl) symptoms arise first and mood disorders occur later, while in other patients the reverse appears to happen. Possible mechanisms for gut-brain dysfunction have been identified, with systemic minimal inflammation as a causal factor in at least some subjects. Other mechanisms that play a role in FGID include chronic infections, intestinal microbiota, low-grade mucosal inflammation including the increase of eosinophils,
\end{abstract}

systemic immune activation, altered intestinal permeability, in diarrhea predominant IBS altered bile salt metabolism, abnormalities in the serotonin metabolism and genetic factors. All these factors might be modulated by environmental factors such as diet. Key Messages: While a number of factors can be linked to specific symptoms (e.g., pain or diarrhea), it is evident that the symptom-based categorization of patients will not allow targeted treatments that specifically address the underlying pathophysiology.

(C) 2018 The Author(s)

Published by S. Karger AG, Basel

\section{Introduction}

Functional gastrointestinal disorders (FGID) such as functional dyspepsia (FD) or irritable bowel syndrome (IBS) are characterized by chronic or recurrent abdominal symptoms of pain [1], and in the case of IBS, associated with either relief or exacerbation by defecation, or a change in bowel habits [2]. Since the Rome criteria were first introduced in 1994 [3], major progress has been made. When the Rome criteria were established, the diagnosis of FGID essentially indicated that there was no "biologic" cause of symptoms. Thus, the Rome criteria were originally developed to provide guidance

\begin{tabular}{ll}
\hline KARGER & $\begin{array}{l}\text { @ } 2018 \text { The Author(s) } \\
\text { Published by S. Karger AG, Basel }\end{array}$ \\
E-Mail karger@karger.com & $\begin{array}{l}\text { This article is licensed under the Creative Commons Attribution- } \\
\text { NonCommercial-NoDerivatives 4.0 International License (CC BY- } \\
\text { NC-ND) (http://www.karger.com/Services/OpenAccessLicense). } \\
\text { Nww.karger.com/ddi } \\
\text { Usage and distribution for commercial purposes as well as any dis- } \\
\text { tribution of modified material requires written permission. }\end{array}$
\end{tabular}

Dr. Gerald Holtmann

Department of Gastroenterology and Hepatology

Princess Alexandra Hospital

199 Ipswich Road, Woolloongabba QLD 4102 (Australia)

E-Mail g.holtmann@uq.edu.au 


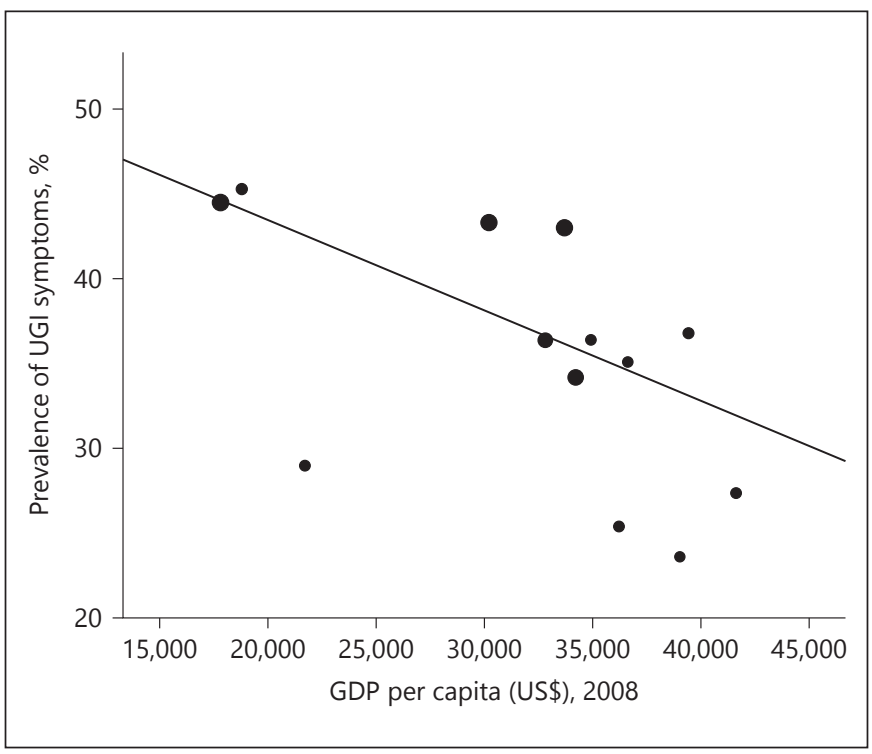

Fig. 1. Correlation between gross domestic product (USD) per capita and the prevalence of upper abdominal symptoms in the population $(r=-0.58, p=0.004)$. The dataset included 23,164 population-based subjects [8]. The size of the bullets reflects the relative sample size (reproduction with permission).

by positively diagnosing (identifying) patients with FGIDs and categorizing patients without a "structural" cause of symptoms. Subsequently, the Rome criteria have shaped the conduct of clinical trials, particularly by defining inclusion and exclusion criteria [4]. By initiating the Rome process 2 decades ago [3], the field has advanced gradually. Awareness of FGID has increased and substantial progress has been made with regard to their epidemiology and pathophysiology. However, this contrasts the very limited progress that has been made with regard to the efficacy of treatment. While the Rome criteria might have been exceptionally valuable in shaping the definitions and recognition of FGID, the failure to include markers for the underlying pathophysiologic mechanisms or response markers into the categorization system, efficacy of treatment has not progressed.

\section{Pathophysiologic Concepts in FGID}

For decades, research in the field of FGID aimed to explore the underlying disease mechanisms centered on alterations of GI motility [5] and visceral sensory function [6]. However, despite the fact that alterations in both motor and sensory functions are probably relevant for the manifestation of symptoms in some patients, in most they may simply represent markers for underlying disturbances [7]. While many exciting therapeutic approaches have been tested, there is no focus on patient care. Ultimately, most novel treatments have failed since the gain over placebo was negligible and/or confined to very small subgroups.

In recent years, a number of mechanisms have been explored. These include disorders of the gut-brain axis, effects of diet, genetic factors, infections and disturbances in the intestinal microbiota, low-grade mucosal inflammation, immune activation, altered intestinal permeability, disordered bile salt metabolism or abnormalities in 5-hydroxytryptamine (5-HT) metabolism. In addition, environmental factors also appear to play a role. Recently, a striking inverse relationship between symptom prevalence and gross domestic product in the respective European countries was observed (Fig. 1) [8].

\section{Gut-Brain Interactions}

Comorbid anxiety and depressive disorders are highly prevalent in patients with FGID and community samples of subjects with FGID symptoms $[9,10]$, and these associations are not explained by healthcare-seeking behavior alone. Thus, it was speculated that the increased prevalence of psychiatric comorbidities in FGID patients reflects the fact that FGID may be a primary manifestation of brain dysfunction [11], or even primary somatization [12], with the brain driving the gut manifestations. The link, however, is more complex. Epidemiological data from 3 prospective studies [13-15] suggest that in at least half of the cases, GI symptoms arise first and incident mood disorders occur later. Other studies emphasize the role of (intestinal) inflammation and cytokine response [16], and the gut microbiome [17] in driving such gut to brain alterations. If these findings hold true, reversing GI dysfunction - which is achievable as the gut is more accessible than the brain - could allow targeting and potentially curing not only the FGID but also concomitant mood disorders.

\section{The Role of Diet}

In the clinical setting, many patients with FGID report links between the ingestion of specific foods and symptoms. Interestingly, these are not reproduced when rechallenge occurs with the offending food in a doubleblind manner [18]. However, diet can change the gastro- 
intestinal microbiome, and this might be a relevant factor for symptoms in FGID [19]. Fermentable oligo-, mono-, and disaccharides and polyols (FODMAPs), which are present in stone fruits, legumes, lactose-containing foods, and artificial sweeteners have been found to exacerbate symptoms in a subgroup of patients due to their fermentation and osmotic effects [20]. Studies using magnetic resonance imaging confirm that when FODMAPs are administered to healthy volunteers, small bowel distension occurs due to increased small bowel water content [21]. While this does not cause symptoms in healthy subjects, in patients with FGID and altered sensory function, FODMAPs induce symptoms in a subset of subjects.

Non-celiac gluten sensitivity is another interesting concept. Some IBS and FD patients, without evidence for celiac disease based on serological markers and histology, experience substantial improvement in symptoms upon withdrawal of gluten from their diet. In a multi-center double-blind placebo-controlled trial, 140 patients with functional GI symptoms were randomized to a strict 3-week gluten-free diet (GFD) [22]. Responders to GFD were asked to continue with the diet, but were re-challenged with gluten or placebo in a double-blind manner. Out of those who met criteria for IBS, 55 (71.4\%) responded to GFD. Of these, 53 then entered the re-challenge phase of the study, and 18 (34.0\%) reported a symptomatic relapse following gluten ingestion. Thus, gluten may cause symptoms in a subgroup of patients without evidence of celiac disease.

\section{Genetic Factors}

In the clinical setting, FGID frequently cluster within families. It has been reported that IBS aggregates in families [23], and twin studies of IBS have shown higher concordance rates among monozygotic twins than dizygotic twins [24]. This suggests that genetic factors may play a role in FGID [25]. It needs to be noted that most studies done so far were hampered by relatively small sample sizes and most genetic association studies of selected candidate genes in FGID have involved less than 2,000 patients and structural lesions (confounders) have not always been properly excluded. However, in FD, many (but not all) studies have observed a link with specific genotypes of the G-protein subunit 825 [26-28]. Overall, the CT genotype appears less likely in FD, while TT and CC are increased. More recently, a mutation of the SCN5A-encoded $\mathrm{Na}(\mathrm{v}) 1.5 \mathrm{Na}^{+}$channel - which is associated with congenital prolonged QT syndrome - has been found to be associated with abdominal pain [29]. Interestingly, this ion-channel is also found in the interstitial cells of Cajal and in the circular smooth muscle in the human GI tract. A pilot study [30] including 49 IBS patients with moderate-to-severe abdominal pain, demonstrated a mis-sense mutation in SCN5A, leading to a loss of function of this channel in one patient. This was not observed in the DNA of 1,500 healthy controls. A subsequent genome-wide association study performed in 584 patients with IBS and 1,380 healthy controls [31] replicated the finding. However, this mutation is only present in approximately $2 \%$ of individuals with IBS. Treatment with the anti-arrhythmic drug mexiletine of one individual with IBS-C resulted in the normalization of bowel habits. This appears to be the first mutation to be linked to IBS and provides strong evidence that genes, albeit uncommonly, can directly induce IBS symptoms.

Other research has focused on genes related to immune regulation and epithelial barrier function [32], 5-HT signaling [33, 34], cannabinoid receptors [35], and bile acid (BA) synthesis $[36,37]$, with varying results. The largest genome-wide association study to date in IBS contained only around 5,500 individuals [38], which compared with 30 to 40,000 in some inflammatory bowel disease cohorts $[39,40]$, limits the ability to draw firm conclusions.

\section{Evidence for the Role of Infections in FGID}

It is well established that acute enteric infections frequently precede the onset of IBS, (predominantly IBS-D), or other functional GI disorders $[41,42]$. In animal studies with chemically induced colonic inflammation, the severity of inflammation is linked to the severity of subsequent visceral hypersensitivity, which might be an underlying mechanism for the development of symptoms [43]. Further strengthening the concept of GI infections as a critical factor for the pathophysiology of FGID are data from Walker et al. [44]. In their study, GI symptom questionnaires were administered to a random populationbased sample of 745 individuals. Subjects were classified as having IBS according to the Rome III criteria, and histopathological examination of colonic biopsy specimens was undertaken. This demonstrated that 17 individuals had colonic spirochetosis, of whom 6 met criteria for IBS, with a significant odds ratio for IBS among those with spirochatosis of 3.6, compared to those without. Biopsies from those with colonic spirochetosis demonstrated increased eosinophils and lymphoid follicles. 


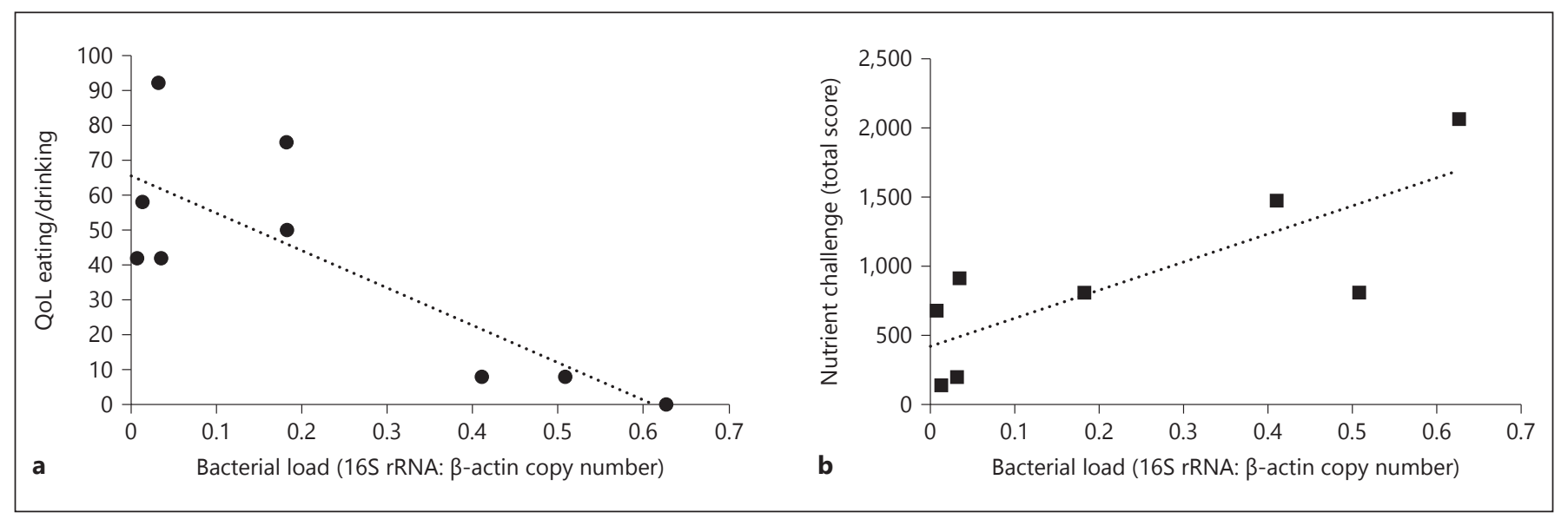

Fig. 2. Duodenal mucosal bacterial load is linked to symptoms in functional dyspepsia (FD). a Reported quality of life (QoL; Nepean Dyspepsia Index) in patients with FD was negatively correlated with bacterial load $(r=-0.8, p=0.01)$. b Total meal-related symptoms reported by patients (nutrient challenge total score) following

More recent data from our group suggest that the density of bacteria colonizing the gastrointestinal mucosa (Fig. 2) plays a key role in the intensity of meal-related symptoms in FD patients and is closely correlated with the impairment of quality of life [45].

While the above study focused on the mucosa-associated microbiome (bacteria permanently colonizing the gut mucosa), many other studies explored the link between the stool microbiome and symptoms. In a casecontrol study of 14 IBS-C patients and 12 sex-matched healthy individuals, analysis of fecal microbiota revealed significantly lower numbers of lactate-producing, lactateutilizing, and hydrogen-consuming bacteria [46]. Following assessment of starch fermentation in vitro, the microbiota of IBS patients produced more sulfides and hydrogen, and less butyrate, than those of healthy controls. Another study assessed intestinal fermentation in 114 patients with Rome III-defined IBS and 33 healthy controls, using intraluminal $\mathrm{pH}$ measured via wireless motility capsule, and levels of short-chain fatty acids in stool [47]. Colonic, but not small bowel, $\mathrm{pH}$ was significantly lower among IBS patients compared with controls, suggesting higher levels of colonic fermentation in IBS. However, levels of short-chain fatty acids were only significantly reduced among those with IBS-C. Others have reported that dysbiosis may lead to excess methane production [48], which can slow the colonic transit and may contribute to constipation in IBS.

Colonization of the small bowel by fermenting bacteria, as in small intestinal bacterial overgrowth (SIBO), has also a standardized test meal positively correlated with bacterial load $(r=0.8, p=0.02)$. Bacterial load was assessed using quantitative PCR and reported as the ratio between copies of the bacterial 16S rRNA and human $\beta$-actin genes. Correlations were assessed using a Spearman correlation (r) [45] (reproduction with permission).

been proposed as a pathophysiological mechanism in FGID [49]. Researchers in the US demonstrated a prevalence of presumed SIBO in individuals with symptoms suggestive of IBS of almost $80 \%$, using lactulose hydrogen breath testing [50]. However, other investigators have not replicated these results [51], despite using similar methodology. In addition, direct aspiration and culture of jejunal secretions, is considered the gold standard for the diagnosis of SIBO, and a study that used this approach failed to detect any increase in the prevalence of SIBO among patients with IBS compared with healthy controls, but there was a significant increase in bacterial load in IBS [52].

Investigators have subsequently treated IBS patients with the antibiotic rifaximin and, in a small placebo-controlled trial, both global symptoms and bloating improved [53]. In 2 large subsequent phase III randomized placebo-controlled trials [54], in non-constipated IBS subjects, significantly higher rates of adequate relief of global IBS symptoms and bloating were reported among those randomized to receive rifaximin, although the benefit over placebo was modest (8-11\% improvement), and none of the trial subjects underwent breath testing to confirm the presence of SIBO. Although these data suggest that the GI microbiota may play a role in symptom generation, the relatively small response rate indicates that a variety of other factors are involved, or rifaximin fails to eradicate the key organisms in most cases.

It is interesting to note that links exist between the brain and the manifestation of symptoms after an acute infection. When Wouters et al. [55] explored risk factors 
for post-infectious IBS (PI-IBS) in a large cohort of subjects exposed to drinking water contaminated with GI pathogens (e.g., norovirus, Giardia lamblia, and Campylobacter jejuni), the risk of developing symptoms consistent with a FGID was higher in subjects with pre-existing anxiety, as well as in younger individuals. The authors also observed an inverse link between anxiety scores and CD4-positive T-lymphocytes expressing interleukin (IL)-2. Interestingly, similar findings have been reported from the Millennium cohort [56] studying individuals in active military service. Anxiety or depression in the setting of acute gastroenteritis increased the risk of subsequent PI-IBS. This suggests a biological link between psychological factors and host susceptibility to infection. Indeed, in animal studies the effect of a chemically induced mucosal inflammation of the colonic visceral sensory function can be augmented if the animals are exposed to a stressor [57]. Thus, the effects of mucosal inflammation are likely modulated by CNS factors while the above data also suggest that gut inflammation alters the brain function.

\section{Evidence for Low-Grade Mucosal Inflammation, Immune Activation, and Altered Intestinal Permeability in FGID}

Numerous studies [58] have demonstrated that lowgrade mucosal inflammation is found in some individuals with IBS or FD [59], if strict criteria are applied. In most patients, no cause can be found. However, it is possible that a thus far unrecognized infective agent contributes to this. This hypothesis is supported by studies that have demonstrated a higher prevalence of symptoms compatible with IBS in individuals with a prior history of acute enteric infection, compared with those without such exposure $[42,60,61]$. The fact that population-based studies demonstrate a link between mucosal eosinophilia in FGID patients and co-existing colonic spirochetosis [44] is also consistent with the concept of an infectious agent $[62,63]$. Besides the histological evidence of mucosal inflammation, some investigators have shown activation of the immune system in patients with IBS, reflected by increased levels of cytokines in the colonic mucosa [64], as well as an increase in release of proinflammatory cytokines from isolated PBMCs, particularly in patients with IBS-D [16], and also in patients with FD [65]. Interestingly, high levels of these cytokines are associated with anxiety and depression $[16,66]$ linking the gut with altered brain function.

Pathophysiology of FGIDs
Whether these findings reflect genuine pathophysiological mechanisms, or are random associations remains unclear. On the contrary, supernatants from cultured PBMCs from IBS-D patients cause hypersensitivity to mechanical stimulation when applied to mouse colonic afferent nerve endings [67]. This effect can be blocked by the tumor necrosis factor- $\alpha$ antagonist infliximab. Interestingly, supernatants from IBS-C patients had no such effect. Analysis of IBS-D supernatants demonstrated elevated levels of the cytokines IL-1 $\beta$, IL-10, tumor necrosis factor- $\alpha$, and IL- 6 among others, and the levels of these appeared to correlate with the frequency and severity of pain.

The cause of this altered immune function remains unclear, but one possible explanation is a defect in the integrity of the GI mucosal epithelial barrier. Subjects with PI-IBS were shown to have increased intestinal permeability, as measured using urinary excretion of lactulose and mannitol, compared with controls [68]. More recent studies in patients with IBS without an infective etiology suggest that a subset of these patients also have abnormal levels of intestinal permeability $[69,70]$, and in one of these studies this increase in permeability correlated significantly with anxiety and depression [70].

\section{Evidence for the Role of Disordered BA Metabolism}

BAs are produced in the liver, released via the bile duct into the duodenum. More than $95 \%$ of BA are reabsorbed in the terminal ileum with the rest passing into the colon, and returning to the hepatocyte via the portal vein, where they are recycled. This leads to the stimulation of the nuclear farnesoid X receptor in the intestinal enterocyte, which induces transcription of fibroblast growth factor-19, which in turn feeds back negatively on the hepatocyte via the fibroblast growth factor- 4 receptor, mediated via the endoplasmic reticulum-resident protein klotho $\beta$, reducing the production of new BA $[71,72]$. For many years, abnormalities of BA metabolism and disordered gut function have been recognized, for example, in patients with terminal ileal Crohn's disease with or without terminal ileal resection, diarrhea is driven by BA entering the colon $[73,74]$. However, only during the last decade has this been addressed in patients with FGID. In cross-sectional surveys, up to $20 \%$ of patients with IBS-D may have evidence of idiopathic BA diarrhea based on 23-seleno 25 -homotaurocholic acid retention scanning $[75,76]$ and interventions with the BA sequestrants have shown improvement in IBS symptoms [75]. However, this does not 
necessarily prove that impaired $\mathrm{BA}$ absorption is a relevant pathophysiologic factor since rapid small intestinal transit may result in impaired BA absorption.

\section{Evidence for the Role of Abnormalities in 5-HT Metabolism}

Serotonin, or 5-HT, is an important neurotransmitter in the brain and the enteric nervous system. The intestinal enterochromaffin cells, which function as sensory transducers of intra-luminal stimuli such as pressure, contain $90 \%$ of the body's total stores of 5-HT [77, 78]. Once released, 5-HT can activate both intrinsic and extrinsic primary afferent neurons, is integral to GI motility, and influences the transmission of information to the central nervous system. The re-uptake of 5-HT by enterocytes is via the serotonin transporter, where it is broken down to 5-hydroxy-indole acetic acid, thereby limiting its action. Therapeutic interventions targeting various 5-HT receptors have been successfully tested in IBS, adding further support to the notion that $5-\mathrm{HT}$ is relevant to the generation of symptoms in IBS in at least some patients [79].

Some of the earliest observations concerning the putative role of 5-HT metabolism in IBS were from studies reporting chronic increases in enterochromaffin cells among individuals who developed PI-IBS, compared with individuals exposed to an acute enteric infection but who recovered [80]. Subsequently, a study that measured 5-HT concentrations in platelet-depleted plasma demonstrated reductions in the release of 5-HT in patients with IBS-C after a standard meal, compared with PI-IBS and healthy individuals, and a higher peak in postprandial 5-HT in PI-IBS than in either IBS-C or healthy controls [81]. Similar results were obtained by another group of investigators in IBS-D, IBS-C, and healthy controls [82].
This study also reported a normal 5-HIAA/5-HT ratio in IBS-C, but a reduced ratio in IBS-D, suggesting that patients with IBS-D may have reduced 5-HT re-uptake, while those with IBS-C have impaired release of $5-\mathrm{HT}$. More recently, uptake of 5-HT by platelets was reduced in patients with IBS-D, and levels of serotonin transporter mRNA in the duodenal mucosa were also reduced [83]. The latter seemed to be associated with duodenal immune activation, with increased numbers of IELs and mast cells being observed, and significant increases in tryptase release. Interestingly, in one study, alterations in 5-HT metabolism in 154 IBS patients did not seem to correlate with GI symptoms, or mood [84]. However, the technical issues of avoiding contamination from platelet release of 5-HT in these studies remain a concern.

\section{Conclusions}

Current data are not consistent with a single overarching pathophysiologic disease model for all FGIDs. Even FGIDs with defined symptoms (e.g., IBS-D) may be caused by a variety of different causes. In the ideal world, diagnostic tests would be applied to identify relevant disease mechanisms and therapeutic interventions selected accordingly. While new knowledge has emerged, this has as yet not translated into more targeted approaches. However, there are areas with rapid progress such as treatments that target the gastrointestinal microbiome which may drive a paradigm shift in the management of FGID.

\section{Disclosure Statement}

The authors have no conflicts of interest to report.

\section{References}

1 Drossman DA: The functional gastrointestinal disorders and the rome III process. Gastroenterology 2006;130:1377-1390.

2 Pimentel M, Talley NJ, Quigley EM, Hani A, Sharara AI, Mahachai V: International perceptions of IBS: survey of IBS investigators from the global multinational IBS initiative. Gastroenterology 2013;144:S203.

3 Drossman DA, Richter J, Talley NJ, Thompson WG, Corraziari E, Whitehead WE: The functional gastrointestinal disorders: Diagnosis, pathophysiology and treatment. Boston, Little Brown, 1994.
4 Irvine EJ, Tack J, Crowell MD, Gwee KA, Ke M, Schmulson MJ, Whitehead WE, Spiegel B: Design of treatment trials for functional gastrointestinal disorders. Gastroenterology 2016;150:1469-1480.e1.

5 Sullivan MA, Cohen S, Snape WJ Jr: Colonic myoelectrical activity in irritable-bowel syndrome. Effect of eating and anticholinergics. N Engl J Med 1978;298:878-883.

6 Ritchie J: Pain from distension of the pelvic colon by inflating a balloon in the irritable colon syndrome. Gut 1973;14:125132.
7 Haag S, Senf W, Tagay S, Heuft G, Gerken G, Talley NJ, Holtmann G: Is there any association between disturbed gastrointestinal visceromotor and sensory function and impaired quality of life in functional dyspepsia? Neurogastroenterol Motil 2010;22:e262e279.

8 Haag S, Andrews JM, Gapasin J, Gerken G, Keller A, Holtmann GJ: A 13-nation population survey of upper gastrointestinal symptoms: prevalence of symptoms and socioeconomic factors. Aliment Pharmacol Ther 2011; 33:722-729. 
9 Henningsen P, Zimmermann T, Sattel H: Medically unexplained physical symptoms, anxiety, and depression: a meta-analytic review. Psychosom Med 2003;65:528-533.

10 Patel P, Bercik P, Morgan DG, Bolino C, Pintos-Sanchez MI, Moayyedi P, Ford AC: Irritable bowel syndrome is significantly associated with somatisation in 840 patients, which may drive bloating. Aliment Pharmacol Ther 2015;41:449-458.

11 Tanaka Y, Kanazawa M, Fukudo S, Drossman DA: Biopsychosocial model of irritable bowel syndrome. J Neurogastroenterol Motil 2011; 17:131-139.

12 Wessely S, Nimnuan C, Sharpe M: Functional somatic syndromes: one or many? Lancet 1999;354:936-939.

13 Koloski NA, Jones M, Kalantar J, Weltman M, Zaguirre J, Talley NJ: The brain - gut pathway in functional gastrointestinal disorders is bidirectional: a 12-year prospective populationbased study. Gut 2012;61:1284-1290.

14 Jones MP, Van Oudenhove L, Talley NJ: Functional gastrointestinal disorders (FGIDS) and psychological disorders: Strong evidence that the link is bidirectional, but psychological distress is more likely to precede a new diagnosis of an FGID. Gastroenterology 2012;142:S570.

15 Koloski NA, Jones MP, Talley NJ: Confirmation of bidirectional gut to brain pathways in irritable bowel syndrome and functional dyspepsia: a one year population-based prospective study. Gastroenterology 2016;150:S737.

16 Liebregts T, Adam B, Bredack C, Roth A, Heinzel S, Lester S, Downie-Doyle S, Smith E, Drew P, Talley NJ, Holtmann G: Immune activation in patients with irritable bowel syndrome. Gastroenterology 2007;132:913-920.

17 Mayer EA, Savidge T, Shulman RJ: Brain-gut microbiome interactions and functional bowel disorders. Gastroenterology 2014;146:15001512.

18 Young E, Stoneham MD, Petruckevitch A, Barton J, Rona R: A population study of food intolerance. Lancet 1994;343:1127-1130.

19 David LA, Maurice CF, Carmody RN, Gootenberg DB, Button JE, Wolfe BE, Ling AV, Devlin AS, Varma Y, Fischbach MA, Biddinger SB, Dutton RJ, Turnbaugh PJ: Diet rapidly and reproducibly alters the human gut microbiome. Nature 2014;505:559-563.

20 Shepherd SJ, Parker FC, Muir JG, Gibson PR: Dietary triggers of abdominal symptoms in patients with irritable bowel syndrome: randomized placebo-controlled evidence. Clin Gastroenterol Hepatol 2008;6:765-771.

21 Murray K, Wilkinson-Smith V, Hoad C, Costigan C, Cox E, Lam C, Marciani L, Gowland P, Spiller RC: Differential effects of fodmaps (fermentable oligo-, di-, mono-saccharides and polyols) on small and large intestinal contents in healthy subjects shown by MRI. Am J Gastroenterol 2014;109:110-119.

22 Elli L, Tomba C, Branchi F, Roncoroni L, Lombardo V, Bardella MT, Ferretti F, Conte D, Valiante F, Fini L, Forti E, Cannizzaro R,
Maiero S, Londoni C, Lauri A, Fornaciari G, Lenoci N, Spagnuolo R, Basilisco G, Somalvico F, Borgatta B, Leandro G, Segato S, Barisani D, Morreale G, Buscarini E: Evidence for the presence of non-celiac gluten sensitivity in patients with functional gastrointestinal symptoms: results from a multicenter randomized double-blind placebo-controlled gluten challenge. Nutrients 2016;8:84.

23 Saito YA, Petersen GM, Larson JJ, Atkinson EJ, Fridley BL, de Andrade M, Locke GR, 3rd, Zimmerman JM, Almazar-Elder AE, Talley NJ: Familial aggregation of irritable bowel syndrome: a family case-control study. Am J Gastroenterol 2010;105:833-841.

24 Lembo A, Zaman M, Jones M, Talley NJ: Influence of genetics on irritable bowel syndrome, gastro-oesophageal reflux and dyspepsia: a twin study. Aliment Pharmacol Ther 2007;25:1343-1350.

25 Adam B, Liebregts T, Holtmann G: Mechanisms of disease: genetics of functional gastrointestinal disorders-searching the genes that matter. Nat Clin Pract Gastroenterol Hepatol 2007;4:102-110.

26 Holtmann G, Siffert W, Haag S, Mueller N, Langkafel M, Senf W, Zotz R, Talley NJ: Gprotein beta 3 subunit 825 CC genotype is associated with unexplained (functional) dyspepsia. Gastroenterology 2004;126:971-979.

27 Oshima T, Nakajima S, Yokoyama T, Toyoshima F, Sakurai J, Tanaka J, Tomita T, Kim Y, Hori K, Matsumoto T, Miwa H: The g-protein beta3 subunit 825 TT genotype is associated with epigastric pain syndrome-like dyspepsia. BMC Med Genet 2010;11:13.

28 de Vries DR, ter Linde JJ, van Herwaarden MA, Smout AJ, Samsom M: Gastroesophageal reflux disease is associated with the C825T polymorphism in the g-protein beta3 subunit gene (GNB3). Am J Gastroenterol 2009;104:281-285.

29 Locke GR 3rd, Ackerman MJ, Zinsmeister AR, Thapa P, Farrugia G: Gastrointestinal symptoms in families of patients with an scn5a-encoded cardiac channelopathy: evidence of an intestinal channelopathy. Am J Gastroenterol 2006;101:1299-1304

30 Saito YA, Strege PR, Tester DJ, Locke GR, 3rd, Talley NJ, Bernard CE, Rae JL, Makielski JC, Ackerman MJ, Farrugia G: Sodium channel mutation in irritable bowel syndrome: evidence for an ion channelopathy. Am J Physiol Gastrointest Liver Physiol 2009;296:G211-G218.

31 Beyder A, Mazzone A, Strege PR, Tester DJ, Saito YA, Bernard CE, Enders FT, Ek WE, Schmidt PT, Dlugosz A, Lindberg G, Karling P, Ohlsson B, Gazouli M, Nardone G, Cuomo R, Usai-Satta P, Galeazzi F, Neri M, Portincasa P, Bellini M, Barbara G, Camilleri M, Locke GR, Talley NJ, D'Amato M, Ackerman MJ, Farrugia G: Loss-of-function of the voltage-gated sodium channel NAV1.5 (channelopathies) in patients with irritable bowel syndrome. Gastroenterology 2014;146:1659-1668.

32 Wouters MM, Lambrechts D, Knapp M, Cleynen I, Whorwell P, Agreus L, Dlugosz A, Schmidt PT, Halfvarson J, Simren M, Ohlsson
B, Karling P, Van Wanrooy S, Mondelaers S, Vermeire S, Lindberg G, Spiller R, Dukes G, D'Amato M, Boeckxstaens G: Genetic variants in CDC42 and NXP1 as susceptibility factors for constipation and diarrhoea predominant irritable bowel syndrome. Gut 2014;63:1103-1111.

33 Grasberger H, Chang L, Shih W, Presson AP, Sayuk GS, Newberry RD, Karagiannides I, Pothoulakis C, Mayer E, Merchant JL: Identification of a functional tph1 polymorphism associated with irritable bowel syndrome bowel habit subtypes. Am J Gastroenterol 2013;108:1766-1774.

34 Jun S, Kohen R, Cain KC, Jarrett ME, Heitkemper MM: Associations of tryptophan hydroxylase gene polymorphisms with irritable bowel syndrome. Neurogastroenterol Motil 2011;23:233-239.e116.

35 Camilleri M, Kolar GJ, Vazquez-Roque MI, Carlson P, Burton DD, Zinsmeister AR: Cannabinoid receptor 1 gene and irritable bowel syndrome: phenotype and quantitative traits. Am J Physiol Gastrointest Liver Physiol 2013; 304:G553-G560.

36 Wong BS, Camilleri M, Carlson P, McKinzie S, Busciglio I, Bondar O, Dyer RB, Lamsam J, Zinsmeister AR: Increased bile acid biosynthesis is associated with irritable bowel syndrome with diarrhea. Clin Gastroenterol Hepatol 2012;10:1009-1015.e3.

37 Wong BS, Camilleri M, Carlson PJ, Guicciardi ME, Burton D, McKinzie S, Rao AS, Zinsmeister AR, Gores GJ: A klothobeta variant mediates protein stability and associates with colon transit in irritable bowel syndrome with diarrhea. Gastroenterology 2011;140:1934-1942.

38 Ek WE, Reznichenko A, Ripke S, Niesler B, Zucchelli M, Rivera NV, Schmidt PT, Pedersen NL, Magnusson P, Talley NJ, Holliday EG, Houghton L, Gazouli M, Karamanolis G, Rappold G, Burwinkel B, Surowy H, Rafter J, Assadi G, Li L, Papadaki E, Gambaccini D, Marchi S, Colucci R, Blandizzi C, Barbaro R, Karling P, Walter S, Ohlsson B, Tornblom H, Bresso F, Andreasson A, Dlugosz A, Simren M, Agreus L, Lindberg G, Boeckxstaens G, Bellini M, Stanghellini V, Barbara G, Daly MJ, Camilleri M, Wouters MM, D'Amato M: Exploring the genetics of irritable bowel syndrome: a GWA study in the general population and replication in multinational casecontrol cohorts. Gut 2015;64:1774-1782.

39 Beaudoin M, Goyette P, Boucher G, Lo KS Rivas MA, Stevens C, Alikashani A, Ladouceur M, Ellinghaus D, Torkvist L, Goel G, Lagace C, Annese V, Bitton A, Begun J, Brant SR, Bresso F, Cho JH, Duerr RH, Halfvarson J, McGovern DP, Radford-Smith G, Schreiber S, Schumm PL, Sharma Y, Silverberg MS, Weersma RK, Quebec IBDGC, Consortium NIG, International IBDGC, D'Amato M, Vermeire S, Franke A, Lettre G, Xavier RJ, Daly MJ, Rioux JD: Deep resequencing of gwas loci identifies rare variants in card9, IL23r and RNF186 that are associated with ulcerative colitis. PLoS Genet 2013;9:e1003723. 
40 Franke A, McGovern DP, Barrett JC, Wang K, Radford-Smith GL, Ahmad T, Lees CW, Balschun T, Lee J, Roberts R, Anderson CA, Bis JC, Bumpstead S, Ellinghaus D, Festen EM, Georges M, Green T, Haritunians T, Jostins L, Latiano A, Mathew CG, Montgomery GW, Prescott NJ, Raychaudhuri S, Rotter JI, Schumm P, Sharma Y, Simms LA, Taylor KD, Whiteman D, Wijmenga C, Baldassano RN, Barclay M, Bayless TM, Brand S, Buning C, Cohen A, Colombel JF, Cottone M, Stronati L, Denson T, De Vos M, D'Inca R, Dubinsky M, Edwards C, Florin T, Franchimont D, Gearry R, Glas J, Van Gossum A, Guthery SL, Halfvarson J, Verspaget HW, Hugot JP, Karban A, Laukens D, Lawrance I, Lemann M, Levine A, Libioulle C, Louis E, Mowat C, Newman W, Panés J, Phillips A, Proctor DD, Regueiro M, Russell R, Rutgeerts P, Sanderson J, Sans M, Seibold F, Steinhart AH, Stokkers PC, Torkvist L, Kullak-Ublick G, Wilson D, Walters T, Targan SR, Brant SR, Rioux JD, D'Amato M, Weersma RK, Kugathasan S, Griffiths AM, Mansfield JC, Vermeire S, Duerr RH, Silverberg MS, Satsangi J, Schreiber S, Cho JH, Annese V, Hakonarson H, Daly MJ, Parkes M: Genome-wide meta-analysis increases to 71 the number of confirmed crohn's disease susceptibility loci. Nat Genet 2010;42: 1118-1125.

41 Ford AC, Thabane M, Collins SM, Moayyedi P, Garg AX, Clark WF, Marshall JK: Prevalence of uninvestigated dyspepsia 8 years after a large waterborne outbreak of bacterial dysentery: a cohort study. Gastroenterology 2010;138:1727-1736; quiz e1712.

42 Marshall JK, Thabane M, Garg AX, Clark WF, Moayyedi P, Collins SM; Walkerton Health Study I: Eight year prognosis of postinfectious irritable bowel syndrome following waterborne bacterial dysentery. Gut 2010;59:605-611.

43 Adam B, Liebregts T, Gschossmann JM, Krippner C, Scholl F, Ruwe M, Holtmann G: Severity of mucosal inflammation as a predictor for alterations of visceral sensory function in a rat model. Pain 2006;123:179-186.

44 Walker MM, Talley NJ, Inganas L, Engstrand L, Jones MP, Nyhlin H, Agreus L, Kjellstrom L, Ost A, Andreasson A: Colonic spirochetosis is associated with colonic eosinophilia and irritable bowel syndrome in a general population in sweden. Hum Pathol 2015;46: 277-283.

45 Zhong L, Shanahan ER, Raj A, Koloski NA, Fletcher L, Morrison M, Walker MM, Talley NJ, Holtmann G: Dyspepsia and the microbiome: time to focus on the small intestine. Gut 2017;66:1168-1169.

46 Chassard C, Dapoigny M, Scott KP, Crouzet L, Del'homme C, Marquet P, Martin JC, Pickering G, Ardid D, Eschalier A, Dubray C, Flint HJ, Bernalier-Donadille A: Functional dysbiosis within the gut microbiota of patients with constipated-irritable bowel syndrome. Aliment Pharmacol Ther 2012;35:828-838.

47 Ringel-Kulka T, Choi CH, Temas D, Kim A, Maier DM, Scott K, Galanko JA, Ringel Y: Al- tered colonic bacterial fermentation as a potential pathophysiological factor in irritable bowel syndrome. Am J Gastroenterol 2015; 110:1339-1346.

48 Kim G, Deepinder F, Morales W, Hwang L, Weitsman S, Chang C, Gunsalus R, Pimentel M: Methanobrevibacter smithii is the predominant methanogen in patients with constipation-predominant IBS and methane on breath. Dig Dis Sci 2012;57:3213-3218.

49 Lin HC: Small intestinal bacterial overgrowth: a framework for understanding irritable bowel syndrome. JAMA 2004;292:852-858.

50 Pimentel M, Chow EJ, Lin HC: Eradication of small intestinal bacterial overgrowth reduces symptoms of irritable bowel syndrome. Am J Gastroenterol 2000;95:3503-3506.

51 Bratten JR, Spanier J, Jones MP: Lactulose breath testing does not discriminate patients with irritable bowel syndrome from healthy controls. Am J Gastroenterol 2008;103:958963.

52 Posserud I, Stotzer PO, Björnsson ES, Abrahamsson H, Simren M: Small intestinal bacterial overgrowth in patients with irritable bowel syndrome. Gut 2007;56:802-808.

53 Pimentel M, Park S, Mirocha J, Kane SV, Kong Y: The effect of a nonabsorbed oral antibiotic (rifaximin) on the symptoms of the irritable bowel syndrome: a randomized trial. Ann Intern Med 2006;145:557-563.

54 Pimentel M, Lembo A, Chey WD, Zakko S, Ringel Y, Yu J, Mareya SM, Shaw AL, Bortey E, Forbes WP, Group TS: Rifaximin therapy for patients with irritable bowel syndrome without constipation. N Engl J Med 2011;364: 22-32.

55 Wouters MM, Van Wanrooy S, Nguyen A, Dooley J, Aguilera-Lizarraga J, Van Brabant W, Garcia-Perez JE, Van Oudenhove L, Van Ranst M, Verhaegen J, Liston A, Boeckxstaens G: Psychological comorbidity increases the risk for postinfectious ibs partly by enhanced susceptibility to develop infectious gastroenteritis. Gut 2016;65:1279-1288.

56 Riddle MS, Welsh M, Porter CK, Nieh C, Boyko EJ, Gackstetter G, Hooper TI: The epidemiology of irritable bowel syndrome in the us military: findings from the millennium cohort study. Am J Gastroenterol 2016;111:93104.

57 Liebregts T, Adam B, Bertel A, Lackner C, Neumann J, Talley NJ, Gerken G, Holtmann G: Psychological stress and the severity of post-inflammatory visceral hyperalgesia. Eur J Pain 2007;11:216-222.

58 Ford AC, Talley NJ: Mucosal inflammation as a potential etiological factor in irritable bowel syndrome: a systematic review. J Gastroenterol 2011;46:421-431.

59 Walker MM, Talley NJ: Review article: Bacteria and pathogenesis of disease in the upper gastrointestinal tract - beyond the era of helicobacter pylori. Aliment Pharmacol Ther 2014;39:767-779.

60 Wensaas KA, Langeland N, Hanevik K, Morch K, Eide GE, Rortveit G: Irritable bow- el syndrome and chronic fatigue 3 years after acute giardiasis: historic cohort study. Gut 2012;61:214-219.

61 Cremon C, Stanghellini V, Pallotti F, Fogacci E, Bellacosa L, Morselli-Labate AM, Paccapelo A, Di Nardo G, Cogliandro RF, De Giorgio $\mathrm{R}$, Corinaldesi R, Barbara G: Salmonella gastroenteritis during childhood is a risk factor for irritable bowel syndrome in adulthood. Gastroenterology 2014;147:69-77.

62 Mearin F, Perello A, Balboa A, Perona M, Sans M, Salas A, Angulo S, Lloreta J, Benasayag R, Garcia-Gonzalez MA, Perez-Oliveras $M$, Coderch J: Pathogenic mechanisms of postinfectious functional gastrointestinal disorders: results 3 years after gastroenteritis. Scand J Gastroenterol 2009;44:1173-1185.

63 Gwee KA, Collins SM, Read NW, Rajnakova A, Deng Y, Graham JC, McKendrick MW, Moochhala SM: Increased rectal mucosal expression of interleukin lbeta in recently acquired post-infectious irritable bowel syndrome. Gut 2003;52:523-526.

64 Coeffier M, Gloro R, Boukhettala N, Aziz M, Lecleire S, Vandaele N, Antonietti M, Savoye G, Bole-Feysot C, Dechelotte P, Reimund JM, Ducrotte P: Increased proteasome-mediated degradation of occludin in irritable bowel syndrome. Am J Gastroenterol 2010;105: 1181-1188.

65 Liebregts T, Adam B, Bredack C, Gururatsakul M, Pilkington KR, Brierley SM, Blackshaw LA, Gerken G, Talley NJ, Holtmann G: Small bowel homing t cells are associated with symptoms and delayed gastric emptying in functional dyspepsia. Am J Gastroenterol 2011;106:1089-1098.

66 Zhen Y, Chu C, Zhou S, Qi M, Shu R: Imbalance of tumor necrosis factor- $\alpha$ interleukin- 8 and interleukin-10 production evokes barrier dysfunction, severe abdominal symptoms and psychological disorders in patients with irritable bowel syndrome-associated diarrhea. Mol Med Rep 2015;12:5239-5245.

67 Hughes PA, Harrington AM, Castro J, Liebregts T, Adam B, Grasby DJ, Isaacs NJ, Maldeniya L, Martin CM, Persson J, Andrews JM, Holtmann G, Blackshaw LA, Brierley SM: Sensory neuro-immune interactions differ between irritable bowel syndrome subtypes. Gut 2013;62:1456-1465.

68 Marshall JK, Thabane M, Garg AX, Clark W, Meddings J, Collins SM; WEL Investigators: Intestinal permeability in patients with irritable bowel syndrome after a waterborne outbreak of acute gastroenteritis in walkerton, ontario. Aliment Pharmacol Ther 2004;20: 1317-1322.

69 Vazquez-Roque MI, Camilleri M, Smyrk T, Murray JA, O'Neill J, Carlson P, Lamsam J, Eckert D, Janzow D, Burton D, Ryks M, Rhoten D, Zinsmeister AR: Association of HLA-DQ gene with bowel transit, barrier function, and inflammation in irritable bowel syndrome with diarrhea. Am J Physiol Gastrointest Liver Physiol 2012;303:G1262G1269. 
70 Shulman RJ, Jarrett ME, Cain KC, Broussard EK, Heitkemper MM: Associations among gut permeability, inflammatory markers, and symptoms in patients with irritable bowel syndrome. J Gastroenterol 2014;49:14671476.

71 Lundasen T, Galman C, Angelin B, Rudling M: Circulating intestinal fibroblast growth factor 19 has a pronounced diurnal variation and modulates hepatic bile acid synthesis in man. J Intern Med 2006;260:530-536.

72 Triantis V, Saeland E, Bijl N, Oude-Elferink RP, Jansen PL: Glycosylation of fibroblast growth factor receptor 4 is a key regulator of fibroblast growth factor 19-mediated downregulation of cytochrome P450 7a1. Hepatology 2010;52:656-666.

73 Hofmann AF: The syndrome of ileal disease and the broken enterohepatic circulation: cholerheic enteropathy. Gastroenterology 1967;52:752-757.

74 Thaysen EH, Pedersen L: Idiopathic bile acid catharsis. Gut 1976;17:965-970.

75 Bajor A, Tornblom H, Rudling M, Ung KA, Simren M: Increased colonic bile acid expo- sure: a relevant factor for symptoms and treatment in IBS. Gut 2015;64:84-92.

76 Aziz I, Mumtaz S, Bholah H, Chowdhury FU, Sanders DS, Ford AC: High prevalence of idiopathic bile acid diarrhea among patients with diarrhea-predominant irritable bowel syndrome based on rome iii criteria. Clin Gastroenterol Hepatol 2015;13:1650-1655.e2.

77 Berger M, Gray JA, Roth BL: The expanded biology of serotonin. Ann Rev Med 2009;60: 355-366.

78 Gershon MD, Wade PR, Kirchgessner AL, Tamir H: 5-HT receptor subtypes outside the central nervous system. Roles in the physiology of the gut. Neuropsychopharmacology 1990;3:385-395.

79 Gershon MD, Tack J: The serotonin signaling system: from basic understanding to drug development for functional GI disorders. Gastroenterology 2007;132:397-414.

80 Dunlop SP, Jenkins D, Neal KR, Spiller RC: Relative importance of enterochromaffin cell hyperplasia, anxiety, and depression in postinfectious IBS. Gastroenterology 2003; 125:1651-1659.
81 Dunlop SP, Coleman NS, Blackshaw E, Perkins AC, Singh G, Marsden CA, Spiller RC: Abnormalities of 5-hydroxytryptamine metabolism in irritable bowel syndrome. Clin Gastroenterol Hepatol 2005;3:349-357.

82 Atkinson W, Lockhart S, Whorwell PJ, Keevil B, Houghton LA: Altered 5-hydroxytryptamine signaling in patients with constipationand diarrhea-predominant irritable bowel syndrome. Gastroenterology 2006;130:3443.

83 Foley S, Garsed K, Singh G, Duroudier NP, Swan C, Hall IP, Zaitoun A, Bennett A, Marsden C, Holmes G, Walls A, Spiller RC: Impaired uptake of serotonin by platelets from patients with irritable bowel syndrome correlates with duodenal immune activation. Gastroenterology 2011;140:1434-1443. e1.

84 Thijssen AY, Mujagic Z, Jonkers DM, Ludidi $\mathrm{S}$, Keszthelyi D, Hesselink MA, Clemens $\mathrm{CH}$ Conchillo JM, Kruimel JW, Masclee AA: Alterations in serotonin metabolism in the irritable bowel syndrome. Aliment Pharmacol Ther 2016;43:272-282. 